\title{
The Nomenclature of Petrology and Mining.
}

\section{By Sir Richard Redyayne, K.C.B.}

$\mathrm{N}^{\mathrm{o}}$ MENCLATURE in the scientific sense may best be described as a system of technical language by which the objects of any science are described, as, for example, the present language of chemical science, usually termed the modern chemical nomenclature, as distinct from the older and less perfect nomenclature. Consideration is here restricted to nomenclature in relation to petrology and mining, and to emphasising the desirability of working to secure a uniform and simple system in respect thereof, for the variety and complexity prevailing in petrological and mining nomenclature are very considerable and hampering.

A first step towards international universality of definition and name would be to secure unanimity of name, meaning, and notation nationally. Great diversity exists at present, especially in the domain of petrology - a state of disorder which is constantly increasing with the growth of terms and expressions. As demonstrating the doubtfulness or inconclusiveness which persists in petrological definition, one may take such wellknown words as 'freestone', 'coal', ' lignite', and ' ore', all terms in very common use in petrological and mining literature. We find that such diversity of definition exists in regard to these as almost to amount to chaos. For example, in the county of Durham the term 'freestone' is applied to sandstone only; but in the West Riding of Yorkshire, to limestone. Albert H. Fay, of the Department of the Interior, United States of America, in his "Glossary of the Mining and Mineral Industry, 1920", describes freestone as " any stone, especially a sandstone, that may be cut freely in any direction without a tendency to split", which is perhaps as good and workable a definition as could be devised.

In considering the implication of the term ' coal' we are met with a great variety of meanings. Holmes defines coal deposits as a "general name applied to black carbonaceous deposits, derived from accumulations of vegetable debris which have been compacted by diagenesis into firm brittle rocks exhibiting a dull or shining lustre ". Fay's description is not in entire agreement with thisthe reason perhaps being due to a difference of definition of 'lignite'-for he defines coal as " a carbonaceous substance formed from the remains of vegetation by partial decomposition (U.S. Geol. Surv.). A solid and more or less distinctly stratified carbonaceous substance varying in colour from dark brown to black, brittle, combustible, and used as fuel; not fusible without decomposition, and very insoluble. In its formation the vegetable matter appears to have first taken the form of peat, then lignite, and finally bituminous coal. The latter by loss of bitumen has in some places been converted into anthracite or hard coal. Lignite gives a browin powder, coal a black ; lignites contain a large percentage of water and ash."
Here we have an example of the danger of tacking on a description to a definition. The description, as well as the definition, bristles with debatable matter. The stages of formation as set out are by no means agreed: the fact that there is loss of volatile hydrocarbons in coal on the application of heat does not prove that these hydrocarbons exist in the coal in the form of bitumen, bitumen being composed of solid or semi-solid hydrocarbons. Some true coals, again, contain a higher percentage of ash and of moisture than some lignites.

The term 'lignite' is used very loosely. Com. monly, all immature coals are called lignite. It is used to embrace not only true lignites, but brown coals also. According to Holmes, lignite is distinguished from brown coal by containing more than 20 per cent of water, but this is not so. Brown coals are known which contain considerably more than 20 per cent of moisture and some lignites which contain less than that amount. As a matter of fact, lignite is immature coal formed from woodit is found in brown coal deposits-whereas brown coal has earthy characteristics and probably owes its origin to peat, and lignite to the trees which grew where the peat was formed. The term best applied to those so-called black lignites which approximate to true coal-and there are many of them-is that adopted by the United States Geological Survey: 'sub-bituminous' coal.

The importance of a correct definition of 'coal' from a legal point of view alone is very great. The mineral mined at Torbane Hill, in Scotland, will be remembered in this connexion. It was this mineral which Mr. Young first used, in 1856, for the extraction of paraffin oil, which gave the start to mineral oil lamps in Great Britain and was extensively exported to the United States of America. The distillation of oil from this mineral led to much litigation. The great question was whether this mineral was or was not coal. The bulk of the evidence went to prove that it was not coal but a bituminous shale or clay. However, the use of the term 'coal' was retained. The litigation was in part between Mr. Young and the distillers of oil from cannel in England and the producers of petroleum in America, and in part with the owners of the ground from which the mineral was taken.

A commonly accepted definition of 'ore' is " a metalliferous mineral of economic value", and of 'ore deposit" " a rock containing a metalliferous mineral of economic value in such amount that it can be profitably exploited". But these definitions are inadequate and unsatisfactory, for there are ores and ore deposits which, by reason of poverty of metalliferous mineral contained in them, or for other obvious reasons such as difficulty of transport, cannot be profitably exploited at the present time, but may, on the exhaustion of richer deposits and on improvement in transport, be brought

No. 3215, VoL. 127] 
within the category of profitability. A better definition of ore would be "A metalliferous mineral of economic interest ", or Crook's definition in his work on mineralogy, namely, "A metalliferous mineral which owes its economic value to the fact that it is smelted or otherwise treated to obtain a metal.".

Various attempts have been made from time to time to standardise geological nomenclature, notably at the Congrès Géologique International in Paris in 1901, which, however, succeeded only in showing the wide divergence of opinion existing in that respect, and at which no final decisions were made. Holmes, in his book, "The Nomenclature of Petrology", has taken stock of the situation and recorded the existing nomenclature in accordance with its current usage in so far as Britain is concerned. The introduction to this work contains an excellent résumé of the question in relation to petrology. With regard to his statement, "at the present time the field of petrology still contains many uncultivated corners, and, until the whole has become familiar ground, existing systems of classification and nomenclature must be regarded as on probation", there must be general agreement; but there will be considerable divergence of opinion concerning his belief that "stability will be approached not principally as a result of any Committee, international or sectional, but by the co-ordinating work of a single petrological genius, whose authority, the outcome of his own success and influence, will be far superior to the merely temporary and democratic authority of a Committee". It seems to the present writer that a most useful end would be served by setting up, in the first instance, national committees with the object of securing, nationally, uniformity and simplification in naming and classification, and thereafter by an international committee, compounded of representation from the national committees, proceeding to deal with the subject internationally. Perhaps the aid of the League of Nations might, with advantage, be invoked in this connexion.

In regard to mining, except to the extent where the law has stepped in to regulate the industry and thereby brought about accuracy, clarity, and standardisation of definition, the terminology is varied, unsatisfactory, and often chaotic. For example, the simple word 'pit' is applied indiscriminately to indicate a shaft, or a colliery with two or more shafts or pits, and sometimes even to a mine worked by adits. Then, again, the word ' colliery' is used to denote one unit or a collection of units of production under the same management. In respect to these, the French nomenclature is better than ours. Another example is the diversity which exists regarding the terminology applied to a bed of coal. "Seam" is the word used in the north of England, 'mine" in Staffordshire, and 'vein' in Wales. Then the 'floor' of a seam is termed 'pavement' in Scotland and 'thill' in Durham and Northumberland. These and many other examples show the advisability of agreeing among ourselves as to mining nomenclature before entering upon an international conclave, and that when we do discuss the subject internationally we do so in the first instance on broad and simple lines. Agreement is far more likely to be reached if we do not strain at attaining too much in the first instance. What is meant by this will be made clear by the following example.

IItherto it has been impossible to institute proper statistical comparisons between different countries, or make correct deductions in regard to output, consumption, and value of minerals, by reason of the absence of uniformity in statistical records. It was in consequence of this that the Imperial Mineral Resources Bureau, ${ }^{*}$ in the year 1924, drew up a statement of what it conceived to be the essential requirements regarding statistical returns from different parts of the British Empire. Thereafter it engaged upon the work of drafting skeleton forms in which returns should be made in order to meet requirements in the light of the criticisms which the Bureau had received. These forms were submitted to various government departments of Great Britain and the Dominions, India, and the Crown Colonies for criticism and comments, and the forms redrafted to meet the greatest common measure of agreement, being then passed to the economic statistical branch of the League of Nations.

The ultimate end sought to be reached by the Bureau was an ambitious one, namely, to obtain, in respect of each country, statistical returns as to : (a) production, (b) exports, (c) imports, $(d)$ consumption, $(e)$ value, $(f)$ persons employed at mines and quarries, $(g)$ accidents and health; and where possible $(h)$ cost of production, $(i)$ wages, $(j)$ work men's compensation. It was realised, however, that it was not possible to obtain complete and uniform statistics under all these heads.

It must be remembered that in connexion with returns of production and value, these are in many cases given voluntarily to government departments by the mine-owners. Thus, in Great Britain in the case of minerals, under the Metalliferous Mines Act the return of mineral sold is of a voluntary character, whereas in the case of coal the returns as to production and value are compulsory. The variations in respect of weight are very great even with English-speaking nations, the ton sometimes termed the long ton ( $2240 \mathrm{lb}$.), the short ton (2000 lb.), and the metric ton (2204.62 lb.) being in use. The Bureau suggested that within the Empire the long ton should be used, except in certain cases such as the precious metals, in which the usual practice should be followed of giving the weight in troy ounces.

The views of the Imperial Mineral Resources Bureau have been very largely accepted by the International Convention on Economic Statistics held at Geneva in 1928, which in itself must be regarded as a notable achievement; but it now remains for the several countries to implement and bring into effective operation the decision of their representatives. This has not yet been done, though more than two years have passed since the date of the Convention.

* Now the Mineral Department of the Imperial Institute.

No. 3215, VoL. 127] 